Wydział Prawa i Administracji

Uniwersytet Warmińsko-Mazurski w Olsztynie

Sędzia Sądu Najwyższego

\title{
WZORZEC DECYZYJNY WPISANY W ART. 30 § 4 KODEKSU PRACY
}

\author{
Abstract

\section{Decision-making resulting from article $30 \S 4$ of the Labour Code}

The author discusses difficulties concerning the employer's obligation to indicate the reasons for termination of the contract of employment. Firstly, the author analyses stages of decisions - making and possible interpretative patterns, as well as interpreting difficulties. Then, the article presents relations between article $30 \$ 4$ of the Labour Code and article $45 \$ 1$ of the Labour Code. Finally, the author describes time aspect of the termination of the contract from the point of its reasons.

Słowa kluczowe: wypowiedzenie umowy o pracę, rozwiązanie umowy o pracę, proces decyzyjny, wzorce interpretacyjne

Key words: termination of the of the contract of employment, dissolution of the of the contract of employment, decision - making process, interpretative patterns

\section{Wprowadzenie}

Regulacja prawna rozwiązania umowy o pracę za wypowiedzeniem albo bez wypowiedzenia jest konsekwencją koncepcji dualistycznej. Ważny jest nie tylko aspekt materialnoprawny, odwzorowujący relację zachodzącą między przeciwstawnymi interesami stron (a w rezultacie poddający czynność pracodawcy wartościowaniu kryteriami abstrakcyjnymi, takimi jak słuszność, sprawiedliwość, uczciwość), ale również czynnik formalny, za pomocą którego prawodawca wzmacnia trwałość więzi pracowniczej. Zastrzeżenie doniosłości warunków pozamerytorycznych sprawia, że normatywny schemat rozwiązania umowy o pracę ma charakter złożony. Z punktu widzenia pracodawcy ważne jest nie tylko to, czy zachodzą podstawy do dalszego zatrudniania pracownika, ale również czy istnieją warunki ograniczające albo wykluczające zakończenie zobowiązania. Z art. $45 \$ 1 \mathrm{kp}$ i z art. $56 \$ 1$ kp wynika, że każdy z wymienionych czynników samoistnie prowadzi do 
zakwestionowania decyzji pracodawcy. Oznacza to, że dopuszczalne jest sankcjonowanie rozwiązania umowy o pracę nie tylko wówczas, gdy było ono niezasadne, ale również gdy naruszało przepisy formalizujące czynność zatrudniającego. W rezultacie racja obiektywna, leżąca po stronie pracodawcy, nie jest gwarantem uniknięcia ujemnych konsekwencji związanych $\mathrm{z}$ rozwiązaniem stosunku pracy. W opozycji do zastrzeżeń kierowanych do tego rozwiązania można przedstawić wiele argumentów uzasadniających istnienie „przepisów ochronnych”. Problemem jest jednak to, że każdy z nich stymulowany jest autonomicznymi wartościami. Nie da się zatem wypracować jednolitej miary, pozwalającej na uchwycenie ich zakresu i oddziaływania. Możliwe jest jednak postawienie tezy ogólnej. Polega ona na postulacie interpretowania „formalizmów” w sposób ścisły (interpretatio restrictiva). Skoro naruszenie „przepisów o wypowiadaniu umów o pracę” lub „przepisów o rozwiazywaniu umów o pracę" samoistnie prowadzi do roszczeń restytucyjnych, to z uwagi na zasadę dobrowolności pracy ${ }^{1}$ (której beneficjentem jest również pracodawca), nie jest trafne wychodzenie poza klarowny przekaz normatywny. Odtworzenie normy prawnej w części „przemilczanej”, przy wykorzystaniu zasad logiki deontycznej, staje się zatem problematyczne. Zależność ta jest szczególnie widoczna w art. $30 \$ 4 \mathrm{kp}$, który przewiduje, że pracodawca w oświadczeniu o wypowiedzeniu lub rozwiązaniu umowy o pracę zobowiązany jest wskazać przyczynę uzasadniającą zakończenie zatrudnienia.

\section{Stadialność procesu prowadzącego do wskazania przyczyny rozwiązania umowy o prace}

Prawodawca w zwięzły sposób opisał obowiązek z art. $30 \$ 4$ kp. Z określenia „powinna być wskazana przyczyna" nie sposób wyinterpretować sposobu jej określenia, parametrów i właściwości. Lakoniczne odwzorowanie omawianej kwestii ma miejsce również w przepisach prawa międzynarodowego. $Z$ art. 7 Konwencji MOP nr 158 dotyczącej rozwiązania stosunku pracy $\mathrm{z}$ inicjatywy pracodawcy ${ }^{2}$ można wyprowadzić wniosek, że „ważna przyczyna” rozwiązania umowy o pracę powinna być znana pracownikowi. Analogiczna teza płynie z art. 24, części II Zrewidowanej Europejskiej Karty Społecznej otwartej do podpisu 3 maja 1996 r. $^{3}$ (mowa w nim o podaniu uzasadnionego powodu rozwiązania stosunku pracy). W art. $30 \$ 4 \mathrm{kp}$ posłużono się tą samą „ ,hasłową” formułą, co stanowi asumpt do rozwoju wykładni operatywnej.

Orzecznictwo skupiło uwagę na odróżnieniu strony formalnej wskazania przyczyny rozwiązania umowy o pracę (czego wyrazem jest art. $30 \$ 4 \mathrm{kp}$ ) od zasadności tej przy-

1 Mającej umocowanie w art. 11 kp, a także w art. 65 ust. 1 Konstytucji Rzeczpospolitej Polskiej, jak również wynikającej z postanowień konwencji MOP nr 105 o zniesieniu pracy przymusowej (Dz. U. z 1959 r., Nr 39, poz. 240) oraz z art. 8 ust. 3a Międzynarodowego Paktu Praw Obywatelskich i Politycznych otwartego do podpisu w Nowym Jorku dnia 19 grudnia 1966 r. (Dz. U. z 1977 r., Nr 38, poz. 167).

2 Nieratyfikowana przez Polskę, tekst na stronie http://www.mop.pl/doc/html/konwencje/k158. html (dostęp: 15.09.2017).

3 Nieratyfikowanej przez Polskę. 
czyny, o czym stanowi art. $45 \$ 1 \mathrm{kp}^{4}$. Dało to podstawę, po pierwsze, do podkreślenia aspektu ochronnego, przejawiającego się w regule, że sądowa kontrola zasadności rozwiązania umowy o pracę może dotyczyć tylko przyczyny wskazanej w oświadczeniu pracodawcy ${ }^{5}$, a po drugie, do nakreślenia cech stabilizujących przyczynę, tak aby była ona komunikatywna dla pracownika ${ }^{6}$. Stosunkowo mało miejsca judykatura poświęciła umieszczeniu obowiązku z art. $30 \$ 4 \mathrm{kp}$ w procesie decyzyjnym, którego wynikiem jest zakończenie więzi pracowniczej.

Proces rozwiązywania umowy o pracę przebiega etapowo. Pracodawca ma powziąć wiedzę o istotnych okolicznościach. Kolejnym krokiem jest wartościowanie możliwości dalszego zatrudniania pracownika. Ostatni etap sprowadza się do uchwycenia konkluzji w pisemnym przekazie uzasadniającym zakończenie zobowiązania i wręczenie oświadczenia woli pracownikowi. Każde stadium ma odmienną naturę. Pierwsze dotyczy pozyskiwania i przyswajania informacji o pracowniku, drugie odnosi się do reguł zarządzania zasobami ludzkimi, trzecie i czwarte zaś wiąże się z umiejętnością wyartykułowania przeżyć pracodawcy i wręczeniem rozwiązania umowy o pracę. Poszczególne fragmenty procesu powinny korelować z sobą, przy czym ostatnie z nich mają charakter odtwórczy, obrazują stan wiedzy pracodawcy i związane z nim przemyślenia. Pracodawca składa oświadczenie woli i deklaruje przyczyny, które brał pod uwagę. Analiza procesu decyzyjnego pozwala sądzić, że opiera się on na relacji temporalnej. Model zakłada, że pracodawca najpierw posiądzie wiedzę, następnie podejmie decyzję, a na końcu przedstawi ją w piśmie rozwiązującym umowę o pracę. Następczość zdarzeń da się wyinterpretować z art. $30 \$ 4 \mathrm{kp}$. Chociaż skupia on uwagę na uzewnętrznieniu przyczyny, to jednak zobrazowanie rezultatu finalnego nie jest możliwe bez wcześniejszego dowiedzenia się o zdarzeniu (zdarzeniach) do niego prowadzącym. Nie można przy tym utracić z pola widzenia, że wnioskowanie to wzorowane jest na myśleniu a fortiori, a to może okazać się zawodne.

Sumą powyższych rozważań jest wyróżnienie dwóch aspektów. Pierwszy dotyczy relacji przyczynowo-skutkowej, drugi polega na umiejętności komunikowania podjętej

4 Por. wyroki Sądu Najwyższego z dnia 2 września 1998 r. I PKN 271/98, OSNAPiUS 1999, nr 18, poz. 577; z dnia 24 marca 1999 r., I PKN 673/98, Monitor Prawniczy 1999 nr 12, poz. 9; z dnia 19 stycznia 2000 r., I PKN 481/99, OSNAPiUS 2001, nr 11, poz. 373; z dnia 18 kwietnia 2001 r., I PKN 370/00, OSNP 2003, nr 3, poz. 65 oraz z dnia 26 lutego 2003 r. I PK 16/02, OSNP 2004, nr 14, poz. 239.

5 Wyroki Sądu Najwyższego z dnia 1 października 1998 r., I PKN 315/97, OSNAPiUS 1998, nr 14, poz. 427; z dnia 19 lutego 1999 r., I PKN 571/98, OSNAPiUS 2000, nr 7, poz. 266; OSP 2001, nr 4, poz. 56, z glosą A. Wypych-Żywickiej.

6 Wyroki Sądu Najwyższego z dnia 3 lutego 2016 r., I PK 233/15, LEX, nr 1965282; z dnia 13 maja 1998 r., I PKN 105/98, OSNAPiUS 1999, nr 10, poz. 335; z dnia 2 września 1998 r., I PKN 271/98, OSNAPiUS 1999, nr 18, poz. 577; z dnia 10 listopada 1998 r., I PKN 423/98, OSNAPiUS 1999, nr 24, poz. 789; z dnia 21 listopada 2000 r., I PKN 99/00, OSNAPiUS 2002, nr 12, poz. 287 oraz z dnia 8 stycznia 2007 r., I PK 175/06, LEX, nr 448111; z dnia 13 kwietnia 2005 r., II PK 251/04, LEX, nr 483281; z dnia 15 listopada 2006 r., I PK 112/06, LEX, nr 247785; z dnia 24 października 2007 r., I PK 116/07, LEX, nr 465925; z dnia 19 lutego 2009 r., II PK 156/08, LEX, nr 736723; z dnia 9 marca 2010 r., I PK 175/09, LEX, nr 585689; z dnia 11 stycznia 2011 r., I PK 152/10, OSNP 2012, nr 5-6, poz. 62; z dnia 20 stycznia 2014 r., II PK 116/13, LEX, nr 1488758. Zob. też: M. Gersdorf, M. Raczkowski, O formułowaniu przyczyny rozwiązania stosunku pracy, Praca i Zabezpieczenie Społeczne 2013, 8, s. 20-24. 
decyzji. Czyli możliwe jest twierdzenie, że w omawianym przepisie zawarto zarówno czynnik motywacyjny, jak również informacyjny. O ile pierwszy z nich skupia uwagę na osobie pracodawcy, o tyle w drugim dochodzi do zespolenia podmiotowego - nadawca ma wskazać przyczynę rozwiązania umowy o pracę, tak aby odbiorca ją zrozumiał. Spostrzeżenie to sprawia, że $\mathrm{w}$ art. $30 \leqq 4 \mathrm{kp}$ nie chodzi tylko o to, aby pracodawca wskazał przyczynę, lecz także o to, aby była ona „motywacyjnie prawdziwa”. Skupiając się na wątku inspiracyjnym, trzeba uznać, że rolą zatrudniającego jest wskazanie racji, która faktycznie zmotywowała go do rozwiązania umowy o pracę. W przeciwnym razie nie wystąpi wymagana zależność między motywem a konsekwencją.

Opisany wzorzec interpretacyjny trzeba poddać weryfikacji. Punktem wyjścia może być charakterystyka art. $30 \$ 1 \mathrm{kp}$. Przepis dotyczy oświadczenia wiedzy pracodawcy, a nie jego woli. Można stąd wnosić, że przy podaniu przyczyny rozwiązania umowy o pracę nie chodzi o to, czy wskazane okoliczności miały miejsce, czy też nie (ta sfera została zastrzeżona dla art. $45 \$ 1 \mathrm{kp}$ i art. $56 \S 1 \mathrm{kp}$ ), ale o to, czy określona wiedza dotarła do pracodawcy. Analogicznie, nie jest ważne, czy decyzja zatrudniającego była rozsądna i właściwa, ale o to, czy podjęta została ze względu na deklarowane czynniki stymulacyjne. Alternatywą jest przyjęcie, że obowiązek zostaje spełniony przez podanie dowolnej skonkretyzowanej przyczyny (nawet nieprawdziwej). Warto w tym miejscu rozróżnić, że czym innym jest, czy wskazane okoliczności miały miejsce, czy też nie (ujęcie obiektywne), a czym innym to, czy pracodawca faktycznie kierował się komunikowanym uwarunkowaniem (prawda motywacyjna). W orzecznictwie ${ }^{8}$ uważa się, że przyczyna $\mathrm{z}$ art. $30 \$ 4 \mathrm{kp}$ musi być prawdziwa, to jest rzeczywiście istnieć. Nie przeszkadza to twierdzić, że stanowi ona powód, który zdaniem pracodawcy uzasadnia rozwiązanie więzi pracowniczej".

Przedstawione opcje interpretacyjne nie są jednoznaczne. Uznanie, że pracodawca, podając przyczynę rozwiązania umowy o pracę, składa oświadczenie wiedzy, utrudnia posługiwanie się czynnikiem obiektywnym. Wartościowanie zdarzeń z punktu widzenia prawdy i fałszu odbywa się w „sferze zasadności”. Zasób wiedzy, którego emanacją jest podanie przyczyny, może być natomiast weryfikowany z punktu widzenia staranności. Nie jest też wykluczone, że motyw deklarowany przez pracodawcę nie warunkował rozwiązania stosunku pracy (co wcale nie oznacza, że nie miał miejsca).

W obrocie prawnym można wyróżnić co najmniej trzy wypadki, gdy zachodzą wątpliwości co do wyrażonych w trybie art. $30 \$ 4 \mathrm{kpc}$ intencji pracodawcy.

Pierwszy zachodzi wówczas, gdy w chwili rozwiązania umowy o pracę zatrudniający nie znał zdarzeń je uzasadniających. Dotyczy to sytuacji wtórnego usprawiedliwiania własnego działania powodem, o którym pracodawca dowiedział się post factum. Kompilacja

7 Wyrok Sądu Najwyższego z dnia 12 września 2008 r., I PK 22/08, OSNP 2010, nr 3-4, poz. 32.

8 Wskazanie nierzeczywistej przyczyny zrównane zostało z jej niepodaniem - wyroki Sądu Najwyższego z dnia 13 października 1999 r., I PKN 304/99, OSNAPiUS 2001, nr 4, poz. 118, z dnia 17 października 2006 r., II PK 31/06, LEX, nr 950617.

9 Wyrok Sądu Najwyższego z dnia 1 kwietnia 2014 r., I PK 244/13, LEX, nr 1498580. 
tego rodzaju może mieć miejsce w razie posłużenia się w piśmie rozwiązującym umowę o pracę szeroką formułą, znajdującą odzwierciedlenie w wielu znanych i nieznanych pracodawcy okolicznościach.

Drugi polega na tym, że zatrudniający ma wiedzę o okolicznościach kwalifikujących wręczenie oświadczenia woli, jednak nie decyduje się na ten krok. Dopiero później, najczęściej w wyniku zmian niezwiązanych z pracownikiem, powraca do zdarzeń wcześniejszych i podnosi je do rangi istotnych okoliczności determinujących rozwiązanie umowy o pracę. W opisanym przypadku można mieć wątpliwości, czy zachowana została kolejność implikowana przez relację przyczynowo-skutkową lub czy doszło do wystąpienia zależności między przywołanymi zdarzeniami a decyzją pracodawcy.

Trzeci wystąpi, gdy w miejsce prawdziwej przyczyny rozwiązania umowy o pracę pracodawca wskaże uwarunkowania pozorne. Dojdzie wówczas do ukrycia realnych przeżyć zatrudniającego, a w zamian ujawnione zostaną czynniki (prawdziwe lub nieprawdziwe) faktycznie niedecydujące o zamiarze wypowiedzenia umowy o pracę ${ }^{10}$.

Przedstawione zakłócenia opierają się na przeświadczeniu, że obowiązek pracodawcy ma wprawdzie charakter subiektywny, odnosi się jednak do jego rzeczywistych przeżyć. Występowanie przykładów fałszywego wskazania przyczyny uzasadniającej rozwiązanie umowy o pracę nie świadczy per se, że kwestia ta została uregulowana w art. $30 \$ 4 \mathrm{kp}$. Pierwszy i trzeci przykład można ocenić w ramach art. $45 \$ 1$ i art. $56 \$ 1 \mathrm{kp}$ (w związku $\mathrm{z}$ odpowiednim przepisem określającym przyczyny rozwiązania umowy o pracę bez wypowiedzenia). Zweryfikowanie drugiej z opisanych sytuacji tymi kryteriami nie jest efektywne.

\section{Relacja występująca między art. 30 § 4 kp i art. 45 § 1 kp}

Dwie normy prawne mogą pozostawać względem siebie w różnych relacjach. W przepisie art. $30 \$ 4 \mathrm{kp}$ zawarto obowiązek informacyjny pracodawcy, w art. $45 \$ 1 \mathrm{kp}$ i art. $56 \$ 1$ kp zaś wyznaczono kryteria skuteczności rozwiązania umowy o pracę przez

10 Zarówno w doktrynie, jak i orzecznictwie sądowym przyjmuje się, że podanie przez pracodawcę przyczyny pozornej (skrywającej inny rzeczywisty powód rozwiązania umowy o pracę) jest równoznaczne $\mathrm{z}$ brakiem wskazania przyczyny uzasadniającej wypowiedzenie w rozumieniu art. $30 \$ 4 \mathrm{kp}$ i przemawia za uwzględnieniem roszczeń (por. K. Jaśkowski, E. Maniewska, Kodeks pracy. Komentarz, t. I, Warszawa 2012, s. 175 oraz wyroki Sądu Najwyższego z dnia 13 października 1999 r., I PK 304/99, OSNAPiUS 2001, nr 1, poz. 118; z dnia 7 kwietnia 1999 r., I PKN 645/98, OSNAPiUS 2000, nr 11, poz. 420; z dnia 13 kwietnia 1999 r., I PKN 4/99, OSNAPiUS 2000, nr 12, poz. 461; z dnia 20 stycznia 2016 r., II PK 312/14, LEX, nr 1982404). Należy odnotować, że orzecznictwo ma tendencję do rozszerzania zakresu pozorności przyczyny z art. $30 \$ 4$ kp. W wyroku Sądu Najwyższego z dnia 24 października 2013 r., II PK 24/13, OSNP 2014, nr 9, poz. 127 stwierdzono, że pracodawca nie wywiązuje się z obowiązku wynikającego z art. $30 \$ 4$ kp wówczas, gdy albo w ogóle nie wskazuje przyczyny wypowiedzenia, albo kiedy wskazanie przyczyny jest pozorne w tym znaczeniu, że jest ona niedostatecznie jasna, konkretna, a w rezultacie niezrozumiała dla pracownika i niepoddająca się weryfikacji w postępowaniu przed sądem. 
zatrudniającego ${ }^{11}$. Prima facie może się wydawać, że zakresy obu przepisów nie krzyżują się z sobą. Przy bliższym oglądzie okazuje się jednak, że art. $45 \$ 1 \mathrm{kp}$ i art. $56 \$ 1 \mathrm{kp}$ nawiązują do powinności $z$ art. $30 \$ 4 \mathrm{kp}$. Staje się to zrozumiałe po uwzględnieniu, iż rozwiązanie więzi prawnej ma być uzasadnione i nie może naruszać przepisów. Pewne jest, że wadliwość w zakresie podania przyczyny jest jednoznaczna z naruszeniem przepisu o wypowiadaniu umowy o pracę. Nie jest jednak jasne, czy art. $30 \$ 4 \mathrm{kp}$ wchodzi w relację ze sferą zasadności czynności prawnej ${ }^{12}$. Pobieżna ocena prowadzi do odpowiedzi negatywnej. Szczegółowa analiza skłania do refleksji.

Wzorzec zasadności wypowiedzenia umowy o pracę (i odpowiadające mu przyczyny rozwiązania umowy bez wypowiedzenia) ma charakter obiektywny, tymczasem podjęcie i wyrażenie powodu zwolnienia z pracy przekierowuje uwagę na subiektywne odczucia pracodawcy. Oznacza to, że zachowanie warunku z art. $30 \$ 4 \mathrm{kp}$ nie gwarantuje trafności czynności kończącej zatrudnienie. Prawidłowe jest też stanowisko, że obiektywnie słuszne rozwiązanie umowy o pracę nie usprawiedliwi pracodawcy w przypadku naruszenia art. $30 \S 4 \mathrm{kp}^{13}$. Wynika to z tego, że w art. $45 \S 1 \mathrm{kp}$ i art. $56 \S 1 \mathrm{kp}$ wkomponowano kumulatywność przesłanek. Wypowiedzenie ma być uzasadnione (a rozwiązanie umowy bez wypowiedzenia zgodne $\mathrm{z}$ enumeratywnie określonymi przesłankami), a jednocześnie nienaruszające przepisów. W rezultacie formalizm zawarty w art. $30 § 4 \mathrm{kp}$ rzutuje na sferę słuszności. Traci ona na znaczeniu, gdy wystąpiły wady na etapie informowania o przyczynach zakończenia umowy o pracę. W tym kontekście można przyjąć, że subiektywny obowiązek zatrudniającego koresponduje z dwoma aspektami wyrażonymi w art. $45 \S 1 \mathrm{kp}$. Po pierwsze, wada formalna sprawia, iż bezprzedmiotowe jest weryfikowanie zasadności czynności pracodawcy, po drugie, wyartykułowanie przez pracodawcę przyczyny zawęża sferę, w jakiej dochodzi do badania jej trafności.

Przedstawione rozwiązanie, jakkolwiek korzystne dla pracownika, $w$ istocie relatywizuje przesłankę zasadności. Okazuje się, że zasób wiedzy pracodawcy, odzwierciedlenie procesu decyzyjnego prowadzącego do rozwiązania umowy o pracę czy też umiejętność wyrażenia jego przyczyny wpływają na zasadność aktu prowadzącego do zakończenia zatrudnienia. Pracodawca przegra proces sądowy, nawet gdy ma rację, a fundamentem przywrócenia do pracy (uznania wypowiedzenia za bezskuteczne) albo odszkodowania stanie się ułomność o charakterze formalnym. Rozwiązanie tego rodzaju przekierowuje uwagę na czynniki drugorzędne, kosztem tych, które w relacji zobowiązaniowej powinny kształtować konsekwencję czynności prawnej. Korelacja ta upoważnia do restrykcyjnego podejścia względem roli i oddziaływania art. $30 \$ 4 \mathrm{kp}^{14}$. Spojrzenie to daje asumpt do

11 Wyrok Sądu Najwyższego z dnia 18 kwietnia 2001 r., I PKN 370/00, OSNAPiUS 2003, nr 3, poz. 65.

$12 \mathrm{~W}$ orzecznictwie wyrażono pogląd, że wynikający z art. $45 \$ 1 \mathrm{kp}$ wymóg zasadności wypowiedzenia umowy o pracę implikował ustanowienie $\mathrm{w}$ art. $30 \$ 4 \mathrm{kp}$ obowiązku wskazania przez pracodawcę przyczyny zakończenia zatrudnienia - wyrok Sądu Najwyższego z dnia 30 września 2014 r., I PK 33/14, LEX, nr 1537263.

13 Wyrok Sądu Najwyższego z dnia 5 maja 1999 r., I PKN 670/98, OSNAPiUS 2000, nr 13, poz. 510.

14 P. Prusinowski, Funkcje obowiazku podania konkretnej przyczyny uzasadniającej rozwiązanie umowy o prace, Monitor Prawa Pracy 2012, 9, s. 458-462. 
jego wąskiego rozumienia przesłania zawartego w przepisie. Nie jest bowiem wykluczone, że przywiązuje on wagę tylko do ostatecznego rezultatu, to jest wskazania przyczyny, nie odnosi się natomiast do procesu decyzyjnego. Zweryfikowanie tych wątpliwości nie jest możliwe bez rozważania perspektywy czasowej.

\section{Aspekt temporalny}

Rozwiązanie umowy o pracę to proces, którego miarą jest między innymi czas. Można wyróżnić co najmniej cztery zdarzenia wchodzące w skład omawianej procedury. Są nimi: powzięcie przez pracodawcę wiadomości o istotnej okoliczności, podjęcie decyzji, wręczenie pracownikowi oświadczenia woli, ocena jego prawidłowości przez sąd. Sekwencja zdarzeń rozłożona została w czasie, a to oznacza, że z punktu widzenia pracodawcy różna może być wiedza o okolicznościach sprawy w poszczególnych stadiach. Warto w tym miejscu zwrócić uwagę, że problem ten nie występuje, gdy czynność prawna zatrudniającego prześwietlana jest tylko z pozycji zasadności. Założenie, że art. $30 \$ 4 \mathrm{kp}$ odnajduje się zarówno w czynniku informacyjnym, jak i przyczynowo-skutkowym, w powiązaniu z dwoistością przesłanek kwalifikujących z art. $45 \$ 1$ i art. $56 \$ 1 \mathrm{kp}$ prowadzi do wątpliwości. Aby się o tym przekonać, wystarczy postawić pytanie, czy okoliczności nieznane pracodawcy, ujawnione po wręczeniu wypowiedzenia (jednak istniejące wcześniej), a wkomponowujące się w podaną pracownikowi przyczynę rozwiązania umowy o pracę, mogą zaważyć przy ocenie zasadności lub niezasadności wypowiedzenia umowy o pracę (rozwiązania bez wypowiedzenia) ${ }^{15}$. $Z$ jednej strony, nie mogły być one motywem, którym kierował się pracodawca, z drugiej, adresat oświadczenia woli stosownie do posiadanej wiedzy mógł je zrozumieć, a w rezultacie skalkulować przy podjęciu decyzji o odwołaniu się. Sytuacja taka będzie miała miejsce, gdy zarzut pracodawcy polegał na określonej praktyce (zjawisku), zatrudniający jednak przy wręczeniu wypowiedzenia dysponował o nim ograniczoną wiedzą. W skrajnym przypadku pracodawca może nie posiadać żadnej wiedzy, a podana pracownikowi przyczyna, sformułowana bez posiadania danych, ostatecznie okaże się prawdziwa (postępowanie dowodowe wykaże, że poszczególne jej przejawy faktycznie miały miejsce). Na tym przykładzie widać, że skupienie się na przyczynie, przy pominięciu relacji przyczynowo-skutkowej, nie stoi na przeszkodzie zbadania płaszczyzny zasadności. Kierując się postulatem niewychodzenia poza językowy przekaz art. $30 \$ 4 \mathrm{kp}$, prawidłowe wydaje się twierdzenie, że aspekt motywacyjny nie powinien wyprzedzać merytorycznego powodu rozwiązania umowy o pracę.

15 Z pozycji pracownika konkretność przyczyny weryfikowana jest według stanu wiedzy zatrudnionego z chwili złożenia oświadczenia woli - wyrok Sądu Najwyższego z dnia 22 sierpnia 2008 r., I PK 197/07, OSNP 2009, nr 5-6, poz. 65. 
Powyższa kontrowersja nie została wyjaśniona w orzecznictwie. Stwierdza się w nim, że przyczyna wypowiedzenia musi być prawdziwa ${ }^{16}$. Oznacza to, że ma być odniesiona do tego, co istniało lub istnieje realnie, a nie do tego, co dopiero może nastąpić. W rezultacie okoliczność uzasadniająca rozwiązanie umowy o pracę musi istnieć (zdarzyć się) przed wyrażeniem woli przez pracodawcę $e^{17}$. Jedynie wyjątkowo wypowiedzenie umowy może uzasadniać zmiana organizacyjna zakładu pracy (zwłaszcza likwidacja stanowiska pracy), która nastąpi w nieodległym czasie i jest pewna ${ }^{18}$. W orzecznictwie kwalifikuje się taką przyczynę jako rzeczywistą ${ }^{19}$. W rezultacie należy zaznaczyć, że czym innym jest dysharmonia istniejąca między wiedzą pracodawcy a kształtem podanej przyczyny rozwiązującej umowę o pracę, a czym innym relacja temporalna zachodząca między istnieniem lub nieistnieniem powodu zakończenia zatrudnienia i datą rozwiązania stosunku pracy. W pierwszym przypadku pracodawca może naruszyć art. $30 \$ 4 \mathrm{kp}$ (zakładając, że znaczenie ma prawidłowość procesu decyzyjnego), a w drugim dojdzie do uchybienia art. $45 \$ 1 \mathrm{kp}$ lub art. $56 \$ 1 \mathrm{kp}$ (nierzeczywistość przyczyny nie oznacza, że jej nie wskazano).

Analogiczne wątpliwości powstaną w przypadku, gdy zatrudniający powołuje się na prawdziwą i znaną mu okoliczność, jednak od jej ujawnienia upłynął znaczny okres. Występowanie tego rodzaju sekwencji sugeruje, że między wiedzą a wolą pracodawcy może dojść do dysonansu (w ujęciu motywacyjnym). Badanie tak wskazanej przyczyny z punktu widzenia zasadności jest niewystarczające. Staje się to jasne, jeśli weźmie się pod uwagę, że pracownik nie może być zakładnikiem błędu, który dawno temu popełnił, chociażby jego zachowanie w pełni uzasadniało zakończenie umowy o pracę $e^{20} \mathrm{Z}$ metodologicznego punktu widzenia, wobec braku odpowiednika art. $52 \S 2 \mathrm{kp}$, jedynym sposobem odejścia od weryfikowania zasadności podanej przyczyny jest odwołanie się do art. $30 \$ 4 \mathrm{kp}$, który zakłada istnienie związku przyczynowego między uzyskaniem przez pracodawcę wiadomości o naruszeniach a wskazaniem przyczyny uzasadniającej

16 Uchwała pełnego składu Izby Pracy i Ubezpieczeń Społecznych Sądu Najwyższego z dnia 27 czerwca 1985 r., III PZP 10/85, OSNCP 1985, nr 11, poz. 164, teza XI; wyrok Sądu Najwyższego z dnia 21 marca 2001 r., I PKN 312/00, LEX, nr 551016.

17 Wyroki Sądu Najwyższego z dnia 12 grudnia 2013 r., I PK 88/13, OSNP 2015, nr 2, poz. 20; z dnia 17 kwietnia 2014 r., III PK 95/13, OSNP 2015, nr 9, poz. 123.

18 Wyroki Sądu Najwyższego z dnia 13 października 1999 r., I PKN 290/99, OSNAPiUS 2001, nr 4, poz. 110; z dnia 12 grudnia 2001 r., I PKN 733/00, OSNP 2003, nr 23, poz. 569; z dnia 29 marca 2001 r., I PKN 325/00, OSNP 2003, nr 1, poz. 8; z dnia 23 lipca 2008 r., I PK 310/07, LEX, nr 500211.

19 Wyroki Sądu Najwyższego z dnia 29 marca 2001 r., I PKN 291/00, OSNP 2003, nr 2, poz. 30; z dnia 18 grudnia 2002 r., I PK 17/02, OSNP 2004, nr 12, poz. 208; z dnia 12 listopada 2008 r., I PK 71/08, OSNP 2010, nr 9-10, poz. 110; z dnia 3 listopada 2010 r., I PK 93/10, LEX, nr 707852; z dnia 5 lipca 2012 r., I PK 51/12, OSNP 2013, nr 15-16, poz. 168.

20 Dlatego w orzecznictwie postawiono tezę, że przyczyna rozwiązania umowy o pracę nie może być zbyt odległa w czasie, aby nie utraciła waloru aktualności (uchwała pełnego składu Izby Pracy i Ubezpieczeń Społecznych Sądu Najwyższego z dnia 27 czerwca 1985 r., III PZP 10/85, OSNCP 1985, nr 11, poz. 164; wyroki Sądu Najwyższego z dnia 21 września 2001 r., I PKN 612/00, OSNP 2003, nr 16, poz. 383; z dnia 4 listopada 2008 r., I PK 75/08, LEX, nr 517999, z dnia 13 kwietnia 2005 r., II PK 230/04, OSNP 2006, nr 1-2, poz. 5). 
wypowiedzenie umowy o pracę. Nie przekonuje przy tym stanowisko prezentowane w orzecznictwie ${ }^{21}$ przyjmujące, że „zdezaktualizowana” przyczyna wypowiedzenia umowy o pracę świadczy o jej niezasadności.

Z dokonanych rozważań wynika, że zależność zachodząca między komentowanymi przepisami nie jest przejrzysta. Możliwa jest interpretacja zawężająca. W tym znaczeniu rola art. $30 \$ 4 \mathrm{kp}$ ogranicza się do formalnego wskazania przyczyny, stanowiącej płaszczyznę badawczą z art. $45 \$ 1 \mathrm{kp}$. Przekonujące są jednak kontrargumenty, umożliwiające spojrzenie na przepis szerzej, to jest uznanie, że odnosi się on także do domeny motywacyjnej. Problem z wyborem właściwego rozwiązania polega na tym, iż nie można go uzależnić od tego, czy jest ono korzystne, czy też niekorzystne dla pracownika. Dyrektywy wykładni nie odwołują się do tego rodzaju czynnika.

Pogodzenie przedstawionych punktów widzenia jest możliwe po doprecyzowaniu pojęcia „przyczyna”. Chodzi o to, że można ją rozumieć w ujęciu subiektywnym, zważywszy na odczucia pracodawcy, ale także jako byt oderwany od przeżyć zatrudniającego. Autonomiczność przyczyny rozwiązania umowy o pracę wpisuje się w relację zachodzącą na styku art. $30 \$ 4 \mathrm{kp}$ i art. $45 \$ 1 \mathrm{kp}$. W procesie rozwiązania umowy o pracę ustawodawca przypisał pracodawcy i sądowi odmienne role. O ile w pierwszym przypadku znaczenie mają przeżycia pracodawcy i wyrażenie jego wiedzy o danym stanie rzeczy, o tyle w drugim funkcją sądu jest rozważanie i przesądzenie sporu, w którym strony kierują się przeciwstawnymi interesami. W rezultacie przyczynowość na gruncie art. $30 \$ 4 \mathrm{kp}$ nie podlega wartościowaniu z uwagi na kryterium słuszności. Z kolei w świetle art. 45 $\$ 1$ kp ten sam przekaz, o ile jest skonkretyzowany i prawdziwy, podlega weryfikacji obiektywnej. Liczy się wówczas tylko to, czy wskazane przez pracodawcę okoliczności uzasadniały zakończenie umowy o pracę. Kwestia, czy pracodawca o wszystkich aspektach wiedział, nie jest nośna. Oznacza to, że ich ujawnienie po wręczeniu pracownikowi kształtującego oświadczenia woli nie należy utożsamiać z naruszeniem przepisu o wypowiadaniu umowy o pracę. Inaczej rzecz ujmując, mimo iż w art. $30 \$ 4 \mathrm{kp}$ wpisano relację przyczynowo-skutkową, w konfrontacji z zakresem badawczym z art. $45 \$ 1$ i art. $56 \$ 1 \mathrm{kp}$, ukierunkowanym na potrzebę dalszego zatrudnienia, wady motywacyjne leżące po stronie pracodawcy nie powinny dominować, jeśli obiektywnie istnieją przeciwwskazania do kontynuowania więzi pracowniczej. Wskazany rozkład argumentacyjny ulega jednak defragmentacji, gdy pracodawca wprawdzie zasłania się przyczyną rzeczywistą, jednak z uwagi na upływ czasu od dowiedzenia się o niej można mieć wątpliwości, czy faktycznie stanowiła ona główny motyw przy podjęciu decyzji o rozwiązaniu umowy o pracę. W takim wypadku trudno wymagać od sądu, aby badał zasadność przyczyny, która została wykorzystana przez zatrudniającego w sposób instrumentalny. Bardziej przekonuje zapatrywanie, że dochodzi do naruszenia art. $30 \$ 4 \mathrm{kp}$.

21 Wyrok Sądu Najwyższego z dnia 23 listopada 2010 r., I PK 105/10, LEX, nr 686795. 


\section{Zakończenie}

Poruszona problematyka ilustruje trudności stojące przed interpretatorem. Obowiązek „wskazania przyczyny wypowiedzenia lub rozwiązania umowy” stanowi jeden z elementów wzorca decyzyjnego prowadzącego do zakończenia zatrudnienia. Normatywne zaakcentowanie właśnie tej części, przy pominięciu pozostałych fragmentów procesu opartego na relacji przyczynowo-skutkowej, prowadzi do przeciwstawnych wniosków. Kierując się zależnością funkcjonalną, nie sposób uznać, że powinność z art. $30 \$ 4$ kp oderwana jest od przeżyć i motywacji pracodawcy. Zaakcentowanie innych czynników zniechęca jednak do rozszerzania formalnych warunków rozwiązania umowy o pracę. Okazuje się, że logicznym wnioskom wynikającym ze zwrotu „powinna być wskazana przyczyna” można przeciwstawić racje systemowe i funkcjonalne. Korelacja omawianego przepisu $\mathrm{z}$ art. $45 \$ 1 \mathrm{kp} \mathrm{i}$ art. $56 \$ 1 \mathrm{kp}$ przekierowuje uwagę na aspekt informacyjny, dezawuując tym samym wątek motywacyjny. Mimo że uregulowanie rozwiązania umowy o pracę zostało oparte na koncepcji dualistycznej, przewidującej dla pracownika roszczenia zarówno w przypadku niezasadności czynności prawnej pracodawcy, jak i w przypadku naruszenia przepisów, z funkcjonalnego punktu widzenia zasadnicze znaczenie ma to, czy zatrudniający słusznie zdecydował o zakończeniu zobowiązania. Paradygmat ten ogranicza doniosłość art. $30 \$ 4 \mathrm{kp}$. Skoro przepis nakłada obowiązek, to nie powinien być on rozbudowywany o fragmenty wprost niewyrażone, a które dają pracownikowi prawo do dochodzenia roszczeń. Wnioskowanie a fortiori jest w tym wypadku zawodne. Bardziej przekonujące jest stanowisko, że wypełnienie art. $30 \leqq 4 \mathrm{kp}$ następuje przez wskazanie przyczyny rozwiązania umowy, a różnego rodzaju wadliwości motywacyjne nie są doniosłe ( $\mathrm{z}$ wyjątkiem przypadku opisanego powyżej).

\section{Bibliografia}

Gersdorf M., Raczkowski M., O formułowaniu przyczyny rozwiązania stosunku pracy, Praca i Zabezpieczenie Społeczne 2013, 8.

Jaśkowski K., Maniewska E., Kodeks pracy. Komentarz, t. I, Warszawa 2012.

Prusinowski P., Funkcje obowiązku podania konkretnej przyczyny uzasadniającej rozwiązanie umowy o prace, Monitor Prawa Pracy 2012, 9. 